\title{
PENDIDIKAN POLITIK KEBANGSAAN DAN POLITIK ISLAM DALAM KURIKULUM MADRASAH ALIYAH MASA ORDE BARU
}

\author{
Maftuhah \\ Fakultas Sains dan Teknologi UIN Syarif Hidayatullah, Jakarta, \\ Fakultas Agama Islam Universitas Islam Attahiriyah \\ Jl. Melayu Kecil III No. 15, Jakarta, 12840 \\ e-mail: tutim8@gmail.com
}

\begin{abstract}
Abstrak: Penelitian ini bertujuan untuk menganalisis tarik menarik negara dan agama dalam kurikulum Madrasah Aliyah masa Orde Baru. Analisis dilakukan terhadap pokok bahasan dari empat mata pelajaran yang tampak nyata mengandung muatan politik kebangsaan dan dua mata pelajaran yang sarat dengan muatan politik keislaman, serta perkembangan masing-masing pokok bahasan dalam empat bentuk kurikulum Madrasah Aliyah sepanjang masa Orde Baru. Penelitian kualitatif strukturalisme ini berusaha menemukan tentang pola-pola yang terbentuk dari hubungan atau tarik menarik ini. Dari kajian ini penulis menyimpulkan bahwa Madrasah Aliyah pada masa Orde Baru mengajarkan muatan politik nasionalisme lebih banyak daripada materi pendidikan politik Islam.
\end{abstract}

\begin{abstract}
Political Education of Nationalism and Islamic Politics in the Curriculum of Madrasah Aliyah in the New Order Era. This research aims at analizing relations between state and religion in the curriculum of Madrasah Aliyah in the New Order Era. The study focuses on components from four subjects that include contents of nation politics and two subject instructions that include matters of Islam politics. In this qualitative structuralism study, the author concludes on the patterns formed by such interaction. The author also maintains that Madrasah Aliyah in the New Order Era provided more on the politics of nationalism rather than those of subjects of education of Islamic politics.
\end{abstract}

Kata Kunci: kurikulum, kebangsaan, Islam, politik

\section{Pendahuluan}

Dunia pendidikan pada dasarnya tidak pernah bersih dari ragam pengaruh politik, sosial, budaya, ekonomi, hukum dan ideologi. Masing-masing sistem dan nilai tersebut 
berusaha membakukan dirinya ke dalam perangkat-perangkat pendidikan yang ada, demi transmisi dan transformasi yang diinginkannya terhadap generasi selanjutnya. Landasan filosofis, sosiologis dan yuridis pendidikan, tujuan pendidikan, kurikulum, model-model pembelajaran, sistem evaluasi, dan sistem akreditasi merupakan contoh dari pembakuan tersebut. Pendidikan yang tidak netral seperti ini menjadikan dirinya bukan saja cenderung sebagai gelanggang pertukaran fikiran-kadang-kadang pertentangan pendapat yang berlarut_bahkan kompetisi kepentingan kelompok-kelompok tertentu.

Salah satu kelompok yang sangat berkepentingan terhadap pendidikan adalah penguasa. Dalam sejarah bangsa-bangsa, pendidikan senantiasa dijadikan alat propaganda politik negara atau paling tidak sebagai salah satu institusi sosialisasi politik (politically sozialitation). Dalam negara yang menganut sistem politik dan ideologi demokrasi, arah sosialisasi politik — termasuk dalam lembaga pendidikannya_yang dikembangkan dapat dipastikan bersifat demokratis; untuk negara yang berpaham komunis, propaganda politik yang ditanamkan akan mengarah pada sistem, proses dan budaya politik komunis; dan bagi negara yang berlandaskan agama, sosialisasi politik akan diselaraskan dengan konsepkonsep agama. ${ }^{1}$

Politik memiliki hubungan yang tidak terpisahkan dengan pendidikan. Keduanya memiliki objek sasaran yang sama, yaitu manusia. Pendidikan dapat memantapkan nilai-nilai dan sistem tertentu yang telah ada, atau memindahkan dan melakukan transformasi serta pengembangan nilai-nilai dan sistem baru kepada manusia. Dengan demikian pendidikan dapat mengokohkan sistem politik yang telah berjalan di tengah masyarakat tertentu, atau mengubahnya menjadi sistem politik dalam format yang berbeda. Begitu pula pendidikan dapat mengubah seseorang dari statusnya sebagai warga negara karena terpaksa, menjadi warga negara dengan kesadaran. ${ }^{2}$ Pengokohan dan perubahan yang diciptakan oleh pendidikan tersebut merupakan bagian integral dari fungsi politik pendidikan. Bahkan Aristoteles menyatakan jika dunia pendidikan diabaikan dalam pembentukan budaya politik, maka hal tersebut tidak dapat menjamin kelangsungan suatu negara, bahkan negara berada dalam ancaman serius. ${ }^{3}$

Rezim Orde Baru tampaknya sangat menyadari hal ini. Dalam Instruksi Presiden dinyatakan bahwa pendidikan politik sebagai rangkaian usaha untuk meningkatkan dan memantapkan kesadaran politik dan kenegaraan ditempatkan sebagai bagian integral kerangka pendidikan politik nasional dan bagian yang tidak terpisahkan dari pendidikan

${ }^{1}$ Azyumardi Azra, "Sosialisasi Politik dan Pendidikan Islam," dalam Ismail SM-Abdul Mukti (ed.), Pendidikan Islam, Demokratisasi dan Masyarakat Madani (Yogyakarta: Pustaka Pelajar, 2000), h. 17-18.

${ }^{2}$ Utsman Abdul Mu'iz Ruslan, Pendidikan Politik Ikhwanul Muslimin (Solo: Intermedia, 2000), h. 64.

${ }^{3}$ Aristoteles, Politiea, terj. Ahmad Luthfi Sayyid berjudul Al-Siyâsah (Kairo: Dâr al-Qoumiyah li al-Thibâ‘ah wa al-Nasyr, t.t.), h. 290. 
nasional. ${ }^{4}$ Bahkan, Soetanto menegaskan bahwa bagi Indonesia yang mendasarkan dirinya pada ideologi dan sistem politik Pancasila, pendidikan politik bertujuan untuk mempertahankan eksistensi dan menjamin kelangsungan hidup bangsa dan negara kesatuan Indonesia yang berdasarkan Pancasila dan UUD 1945. ${ }^{5}$ Di dalamnya diajarkan berbagai nilai yang dikandung oleh Pancasila dan UUD 1945, fungsinya sebagai falsafah dan ideologi negara yang melandasi berbagai aktivitas dan proses politik, serta proses sejarah bangsa yang menunjang eksistensi dan kesadaran terhadap ideologi ini, sehingga pada gilirannya diharapkan tercipta generasi yang memiliki budaya politik Pancasila. ${ }^{6}$

Sosialisasi politik di lembaga pendidikan atau dalam istilah lain pendidikan politik dilangsungkan melalui kurikulum. Kurikulum sendiri memiliki beragam definisi. Zais memandang bahwa kurikulum adalah "... a course of subject matters to be mastered" [... sejumlah mata pelajaran yang harus ditempuh murid]. Sementara Caswel dan Campbell menyatakan kurikulum "... to be composed of all the experiences children have under the guidance of theacher" [...seluruh pengalaman siswa yang berada dalam asuhan guru]. ${ }^{8}$ Romine menambahkan bahwa pengalaman belajar itu dapat dilakukan di dalam kelas maupun di luar kelas.

Curriculum is interpreted to mean all of the organized courses, activities, and experiences which pupils have under direction of the school, whether in the classroom or not. ${ }^{9}$ [Kurikulum adalah seluruh mata pelajaran, kegiatan, dan pengalaman yang dirancang dan dilakukan murid di bawah bimbingan sekolah, baik di dalam kelas maupun di luar kelas].

Madrasah Aliyah sebagai salah satu lembaga pendidikan formal di Indonesia niscaya memiliki kurikulum yang mengandung muatan politik atau melangsungkan pendidikan politik. Tetapi, sebagai salah satu lembaga pendidikan formal yang bernafaskan Islam, kurikulum Madrasah Aliyah tidak serta merta hanya memuat pendidikan politik kebangsaan sebagaimana yang diinginkan rezim Orde Baru pada masa itu. Madrasah pada umumnya di Indonesia memainkan peran dalam mempertahankan Islamisme, langsung maupun

${ }^{4}$ Instruksi Presiden Republik Indonesia Nomor 12 Tahun 1982 tentang Pendidikan Politik bagi Generasi Muda dan Keputusan Badan Koordinasi Penyelenggaraan Pembinaan dan Pengembangan Generasi Muda Nomor: 01/BK Tahun 1982 tentang Petunjuk Pelaksanaan Pendidikan Politik Bagi Generasi Muda (Jakarta: Kantor Menteri Negara Pemuda dan Olahraga, 1985), h. 10-11.

${ }^{5}$ L. Soetanto, "Pendidikan Politik, Disiplin Nasional dan Peranan Wanita dalam Pembangunan," dalam Ramdlon Naning (ed.), Pendidikan Politik dan Regenerasi (Yogyakarta: Liberty, 1982), h. 36.

${ }^{6}$ Budaya politik Pancasila dan UUD 1945 adalah keseluruhan dari nilai, keyakinan empirik, dan lambang ekspresif Pancasila dan UUD 1945 yang menentukan terciptanya situasi dalam mana kegiatan politik terselenggara. Lihat M. Panggabean, Pendidikan Politik dan Kaderisasi Bangsa, dalam Ibid, h. 1-2.

${ }^{7}$ Robert S. Zais, Curriculum Principles and Foundations (New York: Harper \& Row Publisher), 1976, h. 7.

${ }^{8}$ Nana Syaodih Sukmadinata, Pengembangan Kurikulum Teori dan Praktek (Bandung: Remaja Rosdakarya, 2007), h. 4.

${ }^{9}$ Ibid. 
tidak langsung karena ia merupakan representasi kelompok Islam yang dalam sejarahnya pernah menginginkan Indonesia menjadi negara Islam.

Penelitian ini memiliki tiga tujuan. Pertama, mengungkap muatan pendidikan politik kebangsaan yang dimasukan dalam kurikulum Madrasah Aliyah masa Orde Baru. Kedua, mengungkap pendidikan politik keislaman yang terdapat dalam kurikulum Madrasah Aliyah masa Orde Baru. Ketiga, mencari dan menilai keseimbangan antara pendidikan politik keislaman dengan pendidikan politik kebangsaan dalam kurikulum Madrasah Aliyah masa Orde Baru.

\section{Metode Penelitian}

Penelitian ini merupakan jenis penelitian kualitatif dengan pendekatan strukturalisme, yaitu suatu pendekatan yang berusaha untuk menarik hubungan antar elemen-elemen dalam pokok bahasan sehingga dapat mengungkapkan makna-makna di balik topik-topik bahasan, sekaligus mengungkapkan logika-logika di balik makna-makna tersebut. ${ }^{10}$

Sumber data utama penelitian ini adalah pokok bahasan-pokok bahasan dalam kurikulum Madrasah Aliyah pada masa Orde Baru, terutama pokok bahasan-pokok bahasan yang berisi tentang pendidikan politik kebangsaan Indonesia (mata pelajaran Kewarganegaraan/PPKn/PMP, PSPB, Tata Negara dan Sejarah Nasional Indonesia) dan muatanmuatan pendidikan politik keislaman (mata pelajaran Fikih/Syariah dan Sejarah Islam). Madrasah Aliyah di masa Orde Baru menggunakan 4 kurikulum yakni kurikulum tahun 1973, kurikulum tahun 1976, kurikulum tahun 1984, dan kurikulum tahun 1994.

Library research merupakan teknik pengumpulan data yang dipakai dalam penelitian ini. Berbagai data dan informasi yang berkaitan dengan permasalahan penelitian diinventarisir dan dipelajari, kemudian dianalisis isinya (content analysis) dengan tiga cara. Pertama, Induksi, yaitu suatu cara yang dipakai untuk mendapatkan ilmu pengetahuan ilmiah dengan bertitik tolak dari pengamatan atas hal-hal yang bersifat khusus, kemudian ditarik kesimpulan yang bersifat umum. Kedua, Deduksi, yaitu suatu cara yang dipakai untuk mendapatkan ilmu pengetahuan ilmiah dengan bertitik tolak dari pengamatan atas hal-hal yang bersifat umum, kemudian ditarik kesimpulan yang bersifat khusus. Ketiga, Komparatif, yaitu suatu cara menganalisis dengan membandingkan suatu informasi atau data dengan informasi atau data yang lain, kemudian menarik kesimpulan.

Semua pokok bahasan yang terdapat dalam data juga dianalisis memakai model analisis sistemik, yakni masing-masing pokok bahasan dilihat maknanya sendiri-sendiri,

${ }^{10}$ Pemahaman tentang strukturalisme dapat dilihat dalam Burhan Bungin (ed.), Analisis Data Penelitian Kualitatif Pemahaman Filosofis dan Metodologis ke Arah Penguasaan Model Aplikasi, cet. 2 (Jakarta: RajaGrafindo Persada, 2003), h. 141-147; Jean Piaget, Strukturalisme, terj. Hermoyo (Jakarta: Yayasan Obor Indonesia, 1995); David E. Apter, Pengantar Analisa Politik, terj. Setiawan Abadi, cet. 2 (Jakarta: LP3ES, 1987), h. 371-384. 
MIQOT Vol. XXXVI No. 2 Juli-Desember 2012

kemudian diperbandingkan secara sistematis, sehingga didapat suatu hasil perbandingan yang relevan dengan tujuan penelitian.

\section{Hasil dan Pembahasan}

\section{Muatan Pendidikan Politik Kebangsaan dalam Kurikulum Madrasah Aliyah}

Di antara sekian mata pelajaran 'umum' di Madrasah Aliyah, pendidikan politik kebangsaan terangkum dalam 4 mata pelajaran, yakni Kewarganegaraan/PMP/PPKn, PSPB, Sejarah Nasional dan Tata Negara.

Kewarganegaraan/Pendidikan Moral Pancasila (PMP)/Pendidikan Pancasila dan Kewarganegaraan (PPKn)

Pelajaran ini pada dasarnya merupakan pendidikan kewarganegaraan (civic education) Indonesia dan ideologi Pancasila yang bertujuan memberi pemahaman dan pembentukan nilai-nilai Pancasila dalam kehidupan sehari-hari, lingkup berbangsa dan bernegara, serta hubungan internasional. Mata pelajaran ini dapat dibagi menjadi 4 bagian pokok bahasan: Moral Pancasila, Kebangsaan, Politik, dan Status Quo.

1) Bidang moral Pancasila yang diajarkan kepada siswa merupakan sosialisasi nilainilai Pancasila sebagai penjabaran moral/etika dari 5 sila Pancasila, seperti takwa sebagai penjabaran etika sila 1; menghargai sebagai penjabaran etika sila ke-2; kerukunan sebagai penjabaran etika sila ke-3; musyawarah sebagi penjabaran etika sila ke-4; keadilan sosial sebagai penjabaran etika sila ke-5. Dikaitkan dengan agama, sosialisasi nilai-nilai Pancasila tersebut dikemukakan dengan pokok bahasan-pokok bahasan yang seragam dengan nilainilai moral agama (terdapat banyak dalam kurikulum 1994). Hal ini mengindikasikan terdapat usaha untuk memberi pemahaman kepada siswa bahwa Pancasila tidak bertentangan dengan ajaran agama. Bahkan dalam kurikulum 1984 lebih khusus lagi, konsep takwa menurut agama Islam dihubungkan dengan sila 1 Pancasila. Tampaknya pokok bahasan ini berusaha untuk memberi pandangan dasar bahwa Pancasila tidak bertentangan dengan ajaran agama Islam. Dilanjutkan dengan konsep-konsep mengenai toleransi beragama dan hubungannya dengan peran negara menunjukan arahan terhadap siswa bahwa negara Indonesia bukan negara agama dan bukan pula negara sekuler. Indonesia adalah negara yang berposisi netral terhadap semua agama, tapi ikut berperan secara politis dalam beberapa aspek kehidupan spiritualitas keagamaan.

2) Materi-materi kebangsaan yang diajarkan kepada siswa memberi pemahaman tentang konsep nasionalisme sebagai keniscayaan masyarakat dunia. Hal ini dapat dilihat dari materi perserikatan dan kerjasama antar bangsa sebagai bentuk penglihatan bagi siswa tentang fenomena tersebut. Materi ini juga memberi pemahaman tentang posisi bangsa Indonesia yang sejajar dengan bangsa-bangsa lain. Dalam kesejajaran inilah, pelajaran ini berusaha mentransmisikan kesatuan dan persatuan bangsa, semangat kebangsaan 
(nasionalisme) dan jiwa patriotisme. Materi-materi tersebut dikuatkan dengan materi doktrin perang, kewiraan, cinta tanah air dan patriotisme. Pendidikan bela negara ini diwujudkan pula dalam materi struktur politik keamanan mulai dari tingkat sekolah sampai dengan tingkat negara (Pramuka, Wanra, Hansip, dan ABRI), dan konsep mobilisasi masa dengan istilah pertahanan keamanan lingkungan.

3) Sehubungan dengan demokrasi yang menjadi paradigma dunia, pelajaran ini berusaha mengaitkan demokrasi dengan Pancasila yang diistilahkan dengan demokrasi Pancasila. Dalam koridor demokrasi Pancasila ini dijelaskan mengenai struktur dan proses politik Indonesia seperti pemerintah pusat dan daerah, pemilu, serta karakter pemerintah yang demokratis dari sudut pandang UUD 1945.

4) Dalam hubungan antara warga negara dan negara (pemerintah), juga penanaman dukungan serta kepercayaan terhadap pemerintah (status quo), mata pelajaran ini memberi pemahaman mengenai makna pembangunan di Indonesia, contoh-contoh pembangunan ekonomi, serta aspek-aspek lain yang mendukung pembangunan tersebut (hak dan kewajiban warga negara, pajak). Pembangunan yang dilakukan pemerintah Orde Baru ini diakhiri secara politis dengan cara menghubungkannya dengan UUD 1945, dan hasil politik yang dirangkum dalam GBHN dan REPELITA.

Dalam kurikulum 1973 mata pelajaran ini disebut Kewarganegaraan. Materi yang diajarkan lebih banyak tentang ketatanegaraan Indonesia seperti bentuk dan kedaulatan negara, dan struktur politik negara Indonesia disertai rumusannya dalam UUD 1945. Pelajaran ini juga mengajarkan tanggung jawab warga negara, identitas bangsa, dan politik luar negeri Indonesia. Mengingat kurikulum ini merupakan kurikulum kewarganegaraan dan kebangsaan pertama untuk Madrasah Aliyah setelah peristiwa G-30S.PKI dan berbagai peristiwa politik lainnya di masa Orde Lama dapat dipahami bahwa materi-materi di dalamnya mengarah pada pemahaman suatu struktur politik dibandingkan dengan materi-materi kewarganegaraan maupun nilai-nilai moral Pancasila. Dalam kurikulum selanjutnya, istilah-istilah dan nilai-nilai Pancasila lebih banyak dimasukan sebagai materi-materi pelajaran.

Karenanya pelajaran ini diberi nama Pendidikan Moral Pancasila. Terakhir pada kurikulum 1994, nama pelajaran ini diganti lagi menjadi Pendidikan Pancasila dan Kewarganegaraan sebagai inisial untuk kumpulan materi-materi pengajaran Kewarganegaraan dan Pancasila sebagai dasar negara dan budaya bangsa. Materi-materi politik kebangsaan yang dimuat dalam pelajaran ini dapat dilihat dalam tabel di bawah ini: 
MIQOT Vol. XXXVI No. 2 Juli-Desember 2012

Tabel I: Bahan Pengajaran Politik

Mata Pelajaran Kewarganegaraan/PMP/PPKn ${ }^{11}$

\begin{tabular}{|c|c|}
\hline Bahan Pen & Keterangan \\
\hline $\begin{array}{l}\text { 1. Moral Pancasila } \\
\text { Takwa, toleransi, menghargai, kebijaksanaan, pengabdian, } \\
\text { kerukunan, persamaan derajat, kemerdekaan beragama, } \\
\text { musyawarah, gotong royong, keselarasan, kasih sayang, } \\
\text { kewaspadaan, ketertiban, kepentingan umum, keramah- } \\
\text { tamahan, keikhlasan, kejujuran, kedisiplinan, saling meng- } \\
\text { hormati, keserasian, kesetiaan, tanggung jawab, keseder- } \\
\text { hanaan, kerjasama, martabat dan harga diri, hidup hemat, } \\
\text { keadilan, kebenaran, kebanggaan, ketaatan, keadilan sosial, } \\
\text { kecintaan, kebulatan tekad, keyakinan, tenggang rasa, pengen- } \\
\text { dalian diri, tolong menolong, hak asasi. } \\
\text { 2. Kebangsaan } \\
\text { Perserikatan dan kerjasama antar bangsa, hak dan kewajiban } \\
\text { warga negara, kesatuan dan persatuan bangsa, perjuangan } \\
\text { kemerdekaan Indonesia, doktrin perang, kewiraan, } \\
\text { patriotisme, pertahanan dan keamanan lingkungan, cinta } \\
\text { tanah air, bendera dan bahasa. } \\
\text { 3. Politik } \\
\text { Demokrasi Pancasila, pemerintahan demokrasi, pemerintah } \\
\text { pusat dan daerah, hukum dan kekuasaan, sistem pemerin- } \\
\text { tahan lainnya, bentuk dan kedaulatan negara, MPR/MPRS, } \\
\text { DPA, DPR, Kekuasaan kehakiman, pemilu, perobahan UUD } \\
\text { Aturan Peralihan/Tambahan. } \\
\text { 4. Status Quo } \\
\text { Pembangunan nasional, perekonomian Indonesia, koperasi, } \\
\text { koperasi sekolah, pajak, transmigrasi, hak dan kewajiban } \\
\text { waroa neoara keseiahteraan sosial nendidikan }\end{array}$ & $\begin{array}{l}\text { Uraian pokok bahasan } \\
\text { diberikan dalam koridor } \\
\text { negara-bangsa (nasio- } \\
\text { nalisme) Indonesia, } \\
\text { Pancasila, UUD 1945, } \\
\text { dan Orde Baru }\end{array}$ \\
\hline
\end{tabular}

\section{Sejarah Nasional Indonesia}

Pelajaran ini bertujuan untuk memupuk semangat kebangsaan dan cinta tanah air, dan mengenali hubungan antar bangsa di dunia, sehingga diharapkan siswa dapat memahami dan menghayati jati diri bangsa serta memiliki wawasan tentang hubungan antar bangsa. Untuk itu pelajaran Sejarah Nasional Indonesia mengajarkan materi-materi yang beruang lingkup panjang mulai dari masa prasejarah daerah-daerah yang kelak menjadi bagian negara Indonesia sampai dengan kondisi bangsa dan negara Indonesia tatkala buku pelajaran tersebut dibuat.

${ }^{11}$ Dikutip dari Kurikulum Madrasah Aliyah Agama Islam Negeri (MAAIN) (Jakarta: Direktorat Jenderal Bimbingan Masyarakat Islam Direktorat Pendidikan Agama, 1973); Kurikulum 1984 Madrasah Aliyah Garis-garis Besar Program Pengajaran (GBPP), Mata Pelajaran: Pendidikan Moral Pancasila (PMP) (t.t.p: Departemen Agama, 1989); Kurikulum Madrasah Aliyah Garis-garis Besar Program Pengajaran (GBPP), Mata Pelajaran: Pendidikan Pancasila dan Kewarganegaraan (PPKn) (t.t.p: Direktorat Jenderal Pembinaan Kelembagaan Agama Islam, 1995/1996). 
Untuk sejarah masa lampau, sebelum terbentuknya bangsa Indonesia, pelajaran ini berusaha menjelaskan berbagai aspek kehidupan politik dan sistem pemerintahan yang pernah hadir di wilayah-wilayah tersebut. Penjelasan materi ini dikondisikan pada akulturasi 3 agama besar, Hindu, Buddha dan Islam, dengan nilai-nilai yang dianut penduduk asli, serta diarahkan pada proses integrasi bangsa Indonesia. Melanjutkan proses integrasi ini perlawanan terhadap kolonialisme, terutama pergerakan-pergerakan kebangsaan, merupakan fakta yang sangat tepat yang ditampilkan bagi terbentuknya nasionalisme Indonesia. Kesamaan sejarah dijajah oleh bangsa Barat yang sama merupakan latar belakang yang ingin diperlihatkan oleh pelajaran Sejarah Nasional Indonesia dalam melahirkan nasionalisme Indonesia dan persatuan atasnya. Perang Dunia II dan perjuangan wilayah-wilayah di luar Indonesia melawan penjajahnya sehingga melahirkan banyak nationstate mengkondisikan pemahaman siswa bahwa nasionalisme adalah fenomena dunia dan hal ini tidak lagi didasarkan pada perjuangan dan persamaan agama, tapi lebih pada penderitaan yang sama dan perjuangan meraih kebebasan yang sama. Begitu juga dengan pertumbuhan nasionalisme di Eropa memberi pandangan yang seragam pada siswa bahwa ideologi politik ini merupakan keniscayaan dunia modern. Dalam pertumbuhan nasionalisme dunia ini, siswa mempelajari beragam sistem politik yang pernah ada di wilayah-wilayah tersebut dan sistem politik baru yang menggantikannya.

Perlawanan terhadap kolonial, dan pergerakan nasional Indonesia di atas di samping menanamkan jiwa patriotisme kepada anak didik, juga memberi pandangan positif terhadap gerakan-gerakan kebangsaan. Bahkan peristiwa-peristiwa sekitar kemerdekaan Indonesia dan usaha-usaha untuk mempertahankannya secara heroik turut mendidikan hal yang sama.

Kehidupan politik bangsa Indonesia dan pemberontakan-pemberontakan terhadap tatanan politik yang ada pasca kemerdekaan disajikan sedemikian rupa sehingga kondisi saat itu digambarkan sangat tidak stabil. Pemberontakan-pemberontakan tersebut diperlihatkan sebagai gerakan-gerakan kontra nasionalisme Indonesia dan memiliki ideologi yang berbeda dengan Pancasila. Khusus untuk UUD 1945 sebagai dasar kehidupan perpolitikan Indonesia dijelaskan dalam pokok bahasan tersendiri yaitu Dekrit Presiden 5 Juli 1959. Pokok bahasan ini memperlihatkan bahwa UUD 1945 merupakan koridor yang sangat tepat dalam sistem politik Indonesia, dan di luar itu berarti pengkhianatan terhadap semangat dan nilai-nilai 1945.

Orde Baru yang menjadi pokok bahasan terakhir dalam kurikulum 1984, dan dibuat lebih luas lagi menjadi beberapa pokok bahasan dalam kurikulum 1994 disajikan sebagai suatu orde yang berhasil dan sangat stabil (status quo). Terutama pada kehidupan sistem politik, rezim ini menampilkan dirinya sebagai pengayom nilai-nilai nasionalisme Indonesia, dan pengemban Pancasila dan UUD 1945. Semua materi pendidikan politik di atas dapat dilihat dalam tabel berikut: 
MIQOT Vol. XXXVI No. 2 Juli-Desember 2012

Tabel 2

Bahan Pengajaran Politik

Mata Pelajaran Sejarah Nasional Indonesia ${ }^{12}$

Bahan Pengajaran

Keterangan

1. Kerajaan-kerajaan masa Hindu-Buddha di Indonesia

2. Kerajaan-kerajaan Islam di Indonesia

3. Kekuasaan Eropa di Indonesia

4. Perlawanan terhadap Kolonialisme

5. Perang Dunia, Latar Belakang dan Perkembangan Demokrasi

a. Pertumbuhan Nasionalisme, Liberalisme dan Ultra Nasionalisme di Eropa

b. Kebangkitan Asia-Afrika dengan Latar Belakang Nasionalisme sebagai Reaksi terhadap Imperialisme Barat

6. Pergerakan Nasional Indonesia

7. Kemerdekaan Indonesia

8. Kehidupan Politik dan Keamanan pasca Kemerdekaan

9. Masa Demokrasi terpimpin

10. Masa Orde Baru

Kurikulum 1976, 1984

Kurikulum 1976

Kurikulum 1976

Kurikulum 1984, 1994

Kurikulum 1984, 1994

\section{Pendidikan Sejarah Perjuangan Bangsa (PSPB)}

Pelajaran ini merupakan pelajaran yang sangat sarat dengan materi-materi politik kebangsaan. Tujuan mata pelajaran ini membentuk jiwa juang anak didik dalam mempertahankan negara dan bangsa Indonesia (sikap patriotisme), dan sudut pandang yang positif terhadap pemerintah Orde Baru pada masa itu (status quo).

Bahan pengajaran PSPB dimulai dengan proklamasi kemerdekaan, sebagai awal berdirinya negara-bangsa Indonesia, dilanjutkan dengan pembentukan struktur politik, beragam fakta heroik mengenai perjuangan dalam mempertahankan kemerdekaan dan identitas negara-bangsa Indonesia yang berlandaskan Pancasila dan UUD 1945. Di dalamnya juga diperlihatkan kesan bahwa ideologi di luar nasionalisme Indonesia yang berlandaskan Pancasila dan UUD 1945 seperti pemberontakan PKI di Madiun dan Negara Islam Indonesia (NII) Kartosuwiryo adalah pelanggaran berat dan bereksistensi semu dengan sebutan pemberontakan bagi PKI dan NII yang ditulis dalam dua tanda petik.

Pengajaran politik di atas dilanjutkan dengan menampilkan fakta-fakta lain yang relatif sama seperti berbagai perundingan diplomatik dalam mempertahankan identitas negara-

${ }^{12}$ Dikutip dari Kurikulum Madrasah Aliyah Agama Islam Negeri (MAAIN); Syafiie Nafsichin, et al., Sejarah Nasional Indonesia Untuk SMA/MAN (Jakarta: Dharma Bhakti, 1981); Kurikulum 1984, Mata Pelajaran: Sejarah Nasional dan Dunia (t.t.p: Departemen Agama, 1989); Kurikulum Madrasah Aliyah, Mata Pelajaran: Sejarah Nasional dan Umum (t.t.p: Direktorat Jenderal Kelembagaan Agama Islam, 1995/1996). 
bangsa Indonesia, pemberontakan-pemberontakan terhadap ideologi Pancasila disertai keberhasilan negara dalam mengatasinya, dan struktur politik yang jatuh bangun silih berganti. Khusus bagi pertahanan terhadap status quo pelajaran ini mengawalinya dengan pemberontakan G-30S/PKI, dilanjutkan dengan proses politik yang terjadi sesudahnya sampai dengan pembentukan Orde Baru, dan sistem politik yang diterapkan oleh pemerintahan Orde Baru. Mata pelajaran ini hanya diberikan dalam kurikulum 1984 untuk semua jenjang kelas dan jurusan. Dalam kurikulum selanjutnya pelajaran ini ditiadakan karena semua materinya dianggap tumpang tindih dengan materi-materi pelajaran lain seperti PMP dan Sejarah Nasional Indonesia. Materi-materi tersebut dapat dilihat dalam tabel berikut:

Tabel 3

Bahan Pengajaran Politik

Mata Pelajaran PSPB ${ }^{13}$

\section{Bahan Pengajaran}

Keterangan

1. Proklamasi Kemerdekaan

2. Misi sekutu yang pertama

3. Maklumat Wakil Presiden nomor X

4. Permulaan perundingan-perundingan Indonesia-Belanda

5. Bank Negara Indonesia 1946

6. Konferensi Malino

7. Aksi Militer I Belanda

8. Konferensi Asia di New Delhi

9. Persetujuan Roem Royen

10. Usaha mendirikan "NII" Kartosuwiryo

11. Konferensi Meja Bundar

12. Peleburan Bekas Anggota KNIL ke dalam APRIS

13. Pembentukan Kabinet Natsir

14. Pemilu

15. Indonesia menjadi anggota $\mathrm{PBB}$

16. Pembatalan Perjanjian KMB

17. Dwi Komando Rakyat

18. Konsepsi Presiden Soekarno

19. Pemulihan keamanan dan ketertiban

20. Perjuangan KAMI

21. Orde Baru

Diberikan secara

22. ASEAN

23. Kegiatan pemuda

24. Pola hidup sederhana

25. Masalah kolonisasi Timor Portugis (Timor Timur)

26. Musyawarah nasional ulama se-Indonesia

27. Pembangunan nasional berencana

28. Landas Kontinen Indonesia

terpisah di kelas 2

dan 3

${ }^{13}$ Dikutip dari Kurikulum 1984, Mata Pelajaran: Pendidikan Sejarah Perjuangan Bangsa (PSPB) (t.t.p: Departemen Agama, 1989). 
MIQOT Vol. XXXVI No. 2 Juli-Desember 2012

\section{Tata Negara}

Pelajaran ini berfungsi sebagai wahana untuk mengembangkan wawasan dan pemahaman siswa tentang tata kehidupan berbangsa dan bernegara di dalam negara Republik Indonesia; dan membina kemampuan siswa untuk berperan serta secara loyal, aktif, kreatif dan konstruktif dalam kehidupan kenegaraan RI yang berlandaskan Pancasila dan UUD 1945. Dengan tujuan itu siswa diberitahu tentang sistem ketatanegaraan Indonesia dalam konteks teori ketatanegaraan pada umumnya, kultur politik negara Indonesia yang berdasarkan Pancasila dan UUD 1945, struktur politik yang dijalankan, dan peran politik Republik Indonesia dalam tata kehidupan politik internasional. Semua aspek ini mengarahkan siswa pada feeling yang positif terhadap negara Republik Indonesia dan sistem politik yang diterapkannya.

Pokok bahasan pelajaran Tata Negara pada dasarnya tidak berbeda baik dalam kurikulum 1984 maupun kurikulum1994. Perbedaan terletak pada urut materi ajar yang tidak sama, dan khusus dalam kurikulum 1994 terdapat usaha untuk membandingkan konsepkonsep ilmu ketatanegaraan secara umum dengan teori ketatanegaraan menurut kajian fikih. Bahan-bahan pengajaran tata negara ini dapat dilihat dalam tabel berikut:

Tabel 4

Bahan Pengajaran Politik

Mata Pelajaran Tata Negara ${ }^{14}$

\section{\begin{tabular}{l|l} 
Bahan Pengajaran & Keterangan
\end{tabular}}

1. Negara Umum

a. Pengertian Ilmu Negara dan Ilmu Ketatanegaraan

b. Pengertian Negara

c. Terjadinya Negara

d. Tujuan dan Fungsi Negara

e. Unsur-unsur Negara

f. Bentuk Negara, Pemerintahan, dan Demokrasi

g. Negara Hukum dan Hak Asasi Manusia

2. Hukum Umum

a. Norma-norma Hukum

b. Tata Hukum

c. Hukum Internasional

3. Politik Umum

a. Pengertian Politik

b. Sistem Kepartaian

c. Sistem Politik Islam

${ }^{14}$ Dikutip dari Kurikulum 1984, Mata pelajaran: Tata Negara (t.t.p: Departemen Agama, 1989); dan Kurikulum Madrasah Aliyah, Mata pelajaran: Tata Negara (t.t.p: Direktorat Jenderal Kelembagaan Agama Islam, 1995/1996). 
4. Tatanegara Indonesia

a. Proklamasi Kemerdekaan RI

b. Pancasila dan UUD 1945

c. Dinamika Ketatanegaraan RI

d. Lembaga-lembaga Negara menurut UUD 1945

e. Pemilu

f. Hak dan Kewajiban Warga Negara RI menurut UUD 1945

g. Demokrasi Pancasila

h. Organisasi Sosial Politik dan Kemasyarakatan

Kurikulum 1994

Kurikulum 1994

5. Posisi Negara RI di Dunia Internasional

a. Organisasi dan Lembaga Internasional

b. Perjanjian Internasional

c. Hubungan dan Hukum Internasional

d. Politik Luar Negeri Indonesia yang Bebas dan Aktif

e. Masalah Regional dan Internasional

f. Hukum dan Perjanjian Internasional menurut Fikih Dirasah

g. Kerjasama Regional dan Internasional menurut Fikih Dirasah
Kurikulum 1984

Kurikulum 1994

Kurikulum 1994

Diawali oleh materi-materi kenegaraan, hukum dan politik yang bersifat umum, pelajaran ini bermaksud memberi pemahaman dasar tentang negara-bangsa sebagai organisasi kekuasaan dan unsur-unsurnya, tata hukum dan sistem politik yang berlaku dalam sebuah negara-bangsa dalam hubungan tata kerja antar lembaga negara, warga negara dengan negara, dan negara dengan negara lain. Dalam koridor demikian materi dilanjutkan dengan penyempitan yang mengarah pada tata kehidupan kenegaraan RI, sistem politik dan tata hukum yang diberlakukan pada saat itu. Terakhir, siswa diarahkan pada kenyataan Indonesia sebagai salah satu negara-bangsa di antara negara-bangsanegara-bangsa lain di dunia dan berbagai hubungan yang sedang dan dapat dilakukan di antara mereka.

Sejalan dengan masalah Hak Asasi Manusia dan demokrasi yang semakin luas menjadi fenomena dunia, kurikulum 1994 memberi tambahan materi tentang Hak Asasi Manusia dan Demokrasi Pancasila. Kemudian hubungan yang semakin dekat antara umat Islam dan pemerintah di era 90-an, serta integrasi dan akomodasi yang dilakukan oleh generasi Islam terhadap konsep-konsep pemerintah telah melahirkan materi-materi pengajaran baru berupa sistem politik Islam dalam konteks negara Republik Indonesia, dan tinjauan Fiqh dirâsah terhadap masalah-masalah internasional serta posisi dan peran negara RI di dunia internasional.

\section{Muatan Pendidikan Politik Islam dalam Kurikulum}

Nilai-nilai Islam politik pada prinsipnya masuk dalam mata pelajaran agama Islam. Mata pelajaran yang secara nyata mengandung muatan politik Islam terdapat dalam 2 mata pelajaran, yakni Fikih/Syariah dan Sejarah Islam. 
MIQOT Vol. XXXVI No. 2 Juli-Desember 2012

\section{Syariah/Fikih}

Mata pelajaran ini dinamakan Syariah dalam kurikulum 1976, dan fikih dalam kurikulum 1973, 1984 dan 1994. Di semua kurikulum, pelajaran ini memuat materi-materi hukum Islam yang relatif sama, yaitu aspek ibadah, mu'âmalah, jenazah, farâ'idh (waris), ath'imah (makanan dan minuman), munakahât (pernikahan), jinayah (pidana), siyâsah (politik), dan pokok-pokok ilmu usul fikih. Perbedaan terletak pada urut materi ajar yang tidak sama. Kurikulum 1973 didahului oleh materijinayah (pidana) dan diakhiri oleh farâtidh (waris). Kurikulum 1976 diawali oleh pemahaman syari'at Islam dan diakhiri dengan konsep masyarakat Islam Indonesia. Sedangkan kurikulum 1984 dan 1994 diawali oleh aspek ibadah (bersuci) dan diakhiri oleh kaidah-kaidah pokok fikih Islam. Pengertian syari'at yang dicantumkan dalam kurikulum 1976 tidak diganti dengan pengertian fikih dalam kurikulum selanjutnya. Hal ini tampaknya usaha untuk mengurangi pemahaman siswa terhadap paradigma dan fungsi Syariah dalam kehidupan umat Islam.

Konsepsi Syariah tersebut ditempatkan sebagai pokok bahasan 1 sebelum siswa mempelajari materi-materi hukum Islam. Di dalamnya diberikan pemahaman dasar mengenai pengertian, tujuan, fungsi, kandungan/materi, beberapa prinsip, kesempurnaan, dan hikmah Syariah, dikuatkan oleh dalil-dalil al-Qur'an dan hadis. Semua ini mengarahkan siswa pada pemahaman bahwa Syariah adalah frame yang bersifat komprehensif dan melingkupi seluruh aspek kehidupan manusia termasuk aspek politik.

Dalam kurikulum selanjutnya pokok bahasan tersebut ditiadakan dan siswa langsung mempelajari materi-materi hukum Islam tanpa diberi pemahaman tentang konsep dasar fikih terlebih dahulu. Di sini terlihat upaya mengurangi pemahaman dan emosi siswa terhadap hukum-hukum Islam, serta memberi pandangan yang parsial terhadap hukum Islam.

Di antara sekian banyak materi hukum Islam yang dicantumkan dalam mata pelajaran ini, pokok bahasan yang memuat nilai-nilai politik Islam adalah Khilâfah (Pemerintahan), Majlis Syurâ, Peradilan Islam dan Jihad (dalam kurikulum 1973 hanya Peradilan Islam).

Dalam pokok bahasan pemerintahan (khilâfah) siswa diberi materi tentang konsep khilâfah dan hikmahnya, kepala negara (khalâfah) dan proses pemilihannya, serta hak dan kewajiban warga negara dalam sudut pandang Islam. Materi-materi ini merupakan materi-materi pendidikan sistem politik Islam yang mencakup struktur politik (lembaga eksekutif), pendidikan kewarganegaraan, dan kultur politik. Begitu pula dengan Majlis Syurâ (Permusyawaratan) yang mengajarkan struktur dan sistem lembaga legislatif dan Peradilan (Qadha) sebagai bagian dari struktur dan sistem lembaga yudikatif diberikan menurut sudut pandang fikih (Islam). Khusus bagi peradilan Islam, meski dicantumkan pokok bahasan tentang peradilan agama di Indonesia, tapi ketentuan-ketentuan hukum (hudud) untuk kasus-kasus kriminal (pidana) dalam ajaran Islam berdasarkan Qur'an dan hadis telah menampakan kenyataan bahwa struktur politik Islam dan operasionalnya kurang mendapat tempat di Indonesia. Semua bahan-bahan pendidikan politik Islam tersebut dapat dilihat dalam tabel berikut: 
Tabel 5

Bahan Pengajaran Politik

Mata Pelajaran Syariah/Fikih ${ }^{15}$

1. Pemerintahan (Khilâfah)

a. Pengertian, dasar, tujuan dan hikmah Khilâfah

Tidak ada dalam

b. Pengertian Khalifah (kepala negara), syarat,syarat, pengangkatan, baiat dan kewajibannya

c. Hak dan kewajiban rakyat

2. Majlis Syurâ (lembaga Permusyawaratan)

a. Pengertian Majlis Syura

b. Pengertian Ahl al-Halli wa al-'Aqdi (wakil-wakil rakyat di lembaga legislatif)

c. Syarat-syarat pengangkatan, dan hak dan kewajiban anggota Majlis Syura

d. Hal-hal yang dimusyawarahkan

e. Hikmah Majlis Syura

3. Peradilan (Qadha)

a. Arti, fungsi, dan hikmah peradilan

b. Hakim

c. Tersangka dan jaksa

d. Saksi dan barang bukti

e. Penggugat, gugatan, dan tergugat

f. Sumpah

4. Perang (Jihâd)

a. Pengertian, hukum, dan tujuan jihad

b. Syarat dan etika perang

c. Tawanan perang

d. Kewajiban panglima perang dan prajurit

e. Salab, ganimah, dan fa $i \mathrm{i}$ (harta rampasan perang)

f. Kewiraan (ketangkasan)

5. Peradilan Agama di Indonesia
a. Dasar hukum
b. Fungsi

kurikulum 1973

Dalam kurikulum 1976

masuk dalam pembahasan Majlis Syurâ

Tidak ada dalam

kurikulum 1973

Tidak ada dalam

kurikulum 1973

Tidak ada dalam

kurikulum 1973

\section{Sejarah Islam}

Pengajaran Sejarah Islam dalam kurikulum Madrasah Aliyah pada dasarnya adalah pengajaran politik karena sebagian besar materi yang diajarkan berupa lintasan perjalanan politik agama Islam dan umatnya. Materi diawali oleh perjalanan dakwah Rasul

${ }^{15}$ Dikutip dari Kurikulum Madrasah Aliyah Islam Negeri (MAAIN); Bidang Studi Syari'ah untuk Madrasah Aliyah jilid 1a, 1b, 2a, 2b, 3a, 3b (t.t.p: Bagian Proyek Peningkatan Mutu Madrasah Aliyah Direktorat Jenderal Pembinaan Kelembagaan Agama Islam, Departemen Agama, 1985/1986); Kurikulum 1984, Mata Pelajaran: Fikih (t.t.p: Departemen Agama, 1989); Kurikulum Madrasah Aliyah, Mata Pelajaran: Fikih (t.t.p: Direktorat Jenderal Kelembagaan Agama Islam, 1995/1996). 
dan aktivitasnya setelah mendirikan komunitas Muslim Madinah (disebut negara Islam pertama) dari sisi politik, yakni berupa berbagai pertempuran yang dilakukan Rasul dan para pengikutnya. Begitu pula halnya dengan perjalanan agama Islam itu sendiri sering digambarkan melalui bentuk-bentuk Daulah (pemerintahan), konflik kekuasaan, dan konfrontasi fisik (perang) dengan kekuasaan-kekuasaan di luar dirinya.

Bentuk-bentuk pemerintahan yang pernah hadir di dunia Islam, seperti pemerintahan Khulafâ' al-Râsyidîn, Bani (Daulah) Umayah, Bani (Daulah) Abbasyiah, dan Kekhalifahan Turki Utsmani merupakan negara/pemerintahan terpopuler yang dicontohkan oleh pelajaran ini. Semua pemerintahan tersebut, ditambah dengan contoh Bani-Bani kecil lain, melandaskan dirinya secara legal (de jure) pada Islam sebagai dasar negara, serta memiliki wilayah luas (bersifat internasional) dengan sebutan wilayah Islam. Materi ini mentransmisikan internasionalisme Islam, atau dengan kata lain Islam tidak didasarkan pada batas teritorial atau bangsa sehingga secara politis umat Islam tunduk pada satu kekuasaan pusat. Meski seluruh pemerintahan Islam tersebut, kecuali pemerintahan Khulafa ar-Rasyidin, disebut kerajaan yang berarti berbentuk kerajaan, bukan berarti bentuk kerajaanlah yang ingin ditampilkan dalam sistem pemerintahan Islam oleh pelajaran ini, karena dalam kurikulum 1973 terdapat satu pokok bahasan khusus tentang pandangan Islam terhadap pemerintahan, sistemnya, dan penyebutan ahli tata negara kepada Rasulullah dan 3 orang Khulafâ' al-Râsyidîn.

Penyajian data mengenai perkembangan dan kondisi agama Islam dan umat Islam di wilayah Asia, Afrika, Eropa dan Amerika pun memberi pemahaman bahwa Islam itu bersifat internasional, melewati batas negara dan bangsa. Ini dikuatkan dengan organisasiorganisasi Islam internasional yang bertujuan menyatukan umat Islam sedunia, yang juga dijelaskan dalam pokok bahasan tersendiri.

Runtuhnya Daulah-Daulah Islam, berbagai perang dalam mempertahankan agama Islam (seperti perang Salib), penjajahan Barat atas wilayah-wilayah Islam mentransmisikan semangat dan emosi jihad membela agama Islam dan sesama Muslim. Semangat jihad ini bersifat universal sebab fakta kehancuran dan perjuangan umat Islam yang ditampilkan dalam beberapa pokok bahasan tersebut bersifat seragam.

Khusus untuk sejarah Islam dan umatnya di Indonesia, pelajaran ini menyajikannya dalam koridor negara-bangsa yang berlandaskan Pancasila. Materi ini dibuat menjadi pokok bahasan tersendiri mulai dari masuknya Islam ke wilayah yang kelak menjadi bagian Indonesia; perkembangannya dalam hubungan dengan penjajah-penjajah Indonesia, penganut agamaagama lain di Indonesia, peran pemerintah dalam mengayomi dan membina umat Islam; serta sumbangan umat Islam terhadap persatuan bangsa Indonesia. Materi-materi ini merupakan arahan terhadap siswa agar menempatkan urusan agama dan umat Islam dalam bingkai nasionalisme Indonesia dan menjadikan Pancasila, bukan Islam, sebagai landasan berbangsa dan bernegara. Materi-materi pendidikan politik Islam yang terdapat dalam mata pelajaran Sejarah Islam ini dapat dilihat dalam tabel di bawah ini: 
Tabel 6

Bahan Pengajaran Politik

Mata Pelajaran Sejarah Islam ${ }^{16}$

\begin{tabular}{|c|c|}
\hline Bahan Pengajaran & Keterangan \\
\hline $\begin{array}{l}\text { 1. Perkembangan Islam masa Nabi } \\
\text { 2. Perkembangan Islam masa Khulafâ' al-Râsyidîn } \\
\text { 3. Perkembangan Islam masa Bani Umayah dan } \\
\text { keruntuhannya } \\
\text { 4. Perkembangan Islam masa Bani Abbasyiah dan } \\
\text { keruntuhan peradabannya } \\
\text { 5. Peradaban Islam Andalusia dan kehancurannya } \\
\text { 6. Perkembangan Islam di luar Bani Abbasyiah } \\
\text { 7. Perang Salib } \\
\text { 8. Kerajaan (Kekhalifahan) Turki Utsmani } \\
\text { 9. Perkembangan Islam di Asia } \\
\text { 10. Perkembangan Islam di Amerika } \\
\text { 11. Perkembangan Islam di Eropa } \\
\text { 12. Islam dan Pemerintahan } \\
\text { 13. Penjajahan bangsa Barat terhadap wilayah Islam } \\
\text { 14. Kebangkitan dunia Islam } \\
\text { 15. Gerakan dan usaha persatuan dunia Islam } \\
\text { - Organisasi-organisasi Islam dunia } \\
\text { - Kerjasama antar negara-negara Islam } \\
\text { (pengertian modern) } \\
\text { 16. Islam di Indonesia } \\
\text { - Perkembangan Islam sejak zaman kerajaan } \\
\text { - Kampai masa sekarang } \\
\text { - Keadaan Islam di Indonesia sebagai negara } \\
\text { Pancasila } \\
\text { 17. Gerakan/usaha persatuan Islam di Indonesia } \\
\text { - Usaha-usaha mempersatukan umat Islam di } \\
\text { Indonesia } \\
\text { - Peranan persatuan umat Islam dalam } \\
\text { pembangunan dan kesatuan bangsa }\end{array}$ & $\begin{array}{l}\text { Kedua materi ini dalam kuri- } \\
\text { kulum } 1984 \text { masuk dalam } \\
\text { pembahasan Bani Abbasyiah. } \\
\text { Sedangkan dalam kurikulum } \\
\text { 1994 keduanya tidak } \\
\text { diajarkan. } \\
\text { Dalam kurikulum } 1973 \\
\text { Kecuali kurikulum } 1973\end{array}$ \\
\hline
\end{tabular}

\section{Hubungan Antara Muatan Politik Kebangsaan dengan Muatan Politik Keislaman dalam Kurikulum Madrasah Aliyah}

Mencermati materi-materi pendidikan politik dalam 6 mata pelajaran yang telah dijabarkan, paling tidak terdapat 3 pola hubungan. Pertama, menampilkan nilai-nilai politik kebangsaan dari sudut pandang Islam. Materi sistem politik Islam dan sudut pandang

${ }^{16}$ Dikutip dari Kurikulum Madrasah Aliyah Islam Negeri (MAAIN); Sejarah dan Kebudayaan Islam untuk Madrasah Aliyah, jilid IA, IB, IIA, IIB, IIIA, IIIB (Semarang: CV Toha Putra, 1981); Kurikulum 1984, Mata Pelajaran: Sejarah dan Peradaban Islam (t.t.p: Departemen Agama, 1989); Kurikulum Madrasah Aliyah, Mata Pelajaran: Sejarah dan Kebudayaan Islam (t.t.p: Direktorat Jenderal Kelembagaan Agama Islam, 1995/1996). 
fikih (hukum Islam) terhadap hukum dan kerjasama antar bangsa dalam mata pelajaran Tata Negara adalah contoh pola ini. Hal ini memberi pemahaman kepada siswa bahwa nation-state bukan masalah dilihat dari hukum Islam, dan sistem politik yang dibangun di dalamnya dengan demikian berada dalam bingkai nasionalisme sebagai ideologi politik negara kebangsaan. Kemudian dalam pelajaran PMP sila pertama Pancasila dijelaskan melalui konsep takwa dalam Islam. Tema ini memberi indikasi bahwa Pancasila sebagai ideologi bangsa Indonesia tidak bertentangan bahkan selaras dengan ajaran Islam.

Tabel 7

Pokok Bahasan Pola Hubungan 1

1. Sistem Politik Islam

Tata Negara

2. Hukum dan Perjanjian Internasional menurut Fiqh Dirâsah

3. Kerjasama Regional dan Internasional menurut Fiqh Dirâsah

4. Takwa

Tata Negara

Tata Negara

Kewarganegaraan/PMP/PPKn

Kedua, menampilkan materi-materi politik Islam dalam koridor kebangsaan. Kerajaankerajaan Islam di Indonesia yang dihadirkan dalam pelajaran Sejarah Nasional Indonesia dapat menjadi salah satu contoh. Materi ini berusaha mengintegrasikan sistem pemerintahan yang berlandaskan Islam ke dalam nation-state Indonesia. Dalam pelajaran Fikih terdapat pokok bahasan tentang Peradilan Agama (Islam) di Indonesia, dan dalam pelajaran Sejarah Islam terdapat materi mengenai perjalanan Islam di Indonesia dari sisi politik, yakni mulai dari kerajaan-kerajaan yang bercorak Islam di masa lampau di wilayah yang kelak disebut Indonesia sampai dengan persatuan umat Islam Indonesia dalam kesatuan negara-bangsa yang berlandaskan Pancasila, bukan berlandaskan Islam. Walaupun diistilahkan dengan Peradilan Agama (yang berarti terdapat Peradilan Non-Agama), materi ini mengkondisikan eksistensi dan peran lembaga peradilan Islam -sebagai bagian dari struktur politik- dalam kerangka sistem politik nasional Indonesia. Hal ini mengajarkan bahwa nasionalisme bukan masalah bagi tegaknya struktur politik Islam, bahkan dapat berfungsi sebagi payung baginya. Selanjutnya keberadaan kerajaan-kerajaan Islam di wilayah-wilayah yang disebut sebagai wilayah Indonesia disertai perjalanannya sampai berubah menjadi negara-bangsa Indonesia memberi penjelasan tunggal, yaitu bentuk negara dalam Islam bersifat fleksibel karena dapat berbentuk kerajaan yang berlandaskan Islam maupun berbentuk Republik yang tidak berlandaskan Islam, seperti Pancasila. Begitu pula ulama sebagai simbol tokoh agama Islam dalam materi PSPB diperlihatkan eksistensinya dalam frame nasional Indonesia dengan judul "Musyawarah Nasional Ulama se-Indonesia"; dan persatuan Islam yang ditempatkan dalam skala nasional sebagaimana yang terdapat dalam mata pelajaran Sejarah Islam dengan pokok bahasan "Gerakan/Usaha Persatuan Islam di Indonesia dalam 
Pembangunan dan Kesatuan Bangsa”. Materi-materi ini menjelaskan bahwa pendidikan politik yang terdapat dalam kurikulum Madrasah Aliyah berusaha mengarahkan siswa untuk melihat Islam dari sudut pandang nasionalisme, bukan nasionalisme dipandang dari konsep Islam. Kondisi ini sebenarnya tidak menguntungkan karena sudut pandang Islam yang tepat terhadap konsep kebangsaan akan memberi bekal kepada anak didik untuk menerima nasionalisme Indonesia sebagai paradigma yang benar dan tidak bertentangan dengan prinsip agama Islam.

Tabel 8

Pokok Bahasan Pola Hubungan 2

\begin{tabular}{|c|c|}
\hline Pokok Bahasan & Mata Pelajaran \\
\hline 1. Kerajaan-kerajaan Islam di Indonesia & Sejarah Nasional Indonesia \\
\hline 2. Peradilan Agama di Indonesia & Fikih \\
\hline 3. Islam di Indonesia & Sejarah Islam \\
\hline $\begin{array}{l}\text { 4. Gerakan/Usaha Persatuan Islam di Indonesia dalam } \\
\text { Pembangunan dan Kesatuan Bangsa }\end{array}$ & Sejarah Islam \\
\hline 5. Musyawarah Nasional Ulama se-Indonesia & PSPB \\
\hline
\end{tabular}

Ketiga, Menampilkan materi-materi Islam politik dan diimbangi dengan materimateri politik kebangsaan. Penjajahan bangsa Barat terhadap wilayah Islam yang memunculkan nasionalisme di dunia Islam sebagaimana yang terdapat dalam mata pelajaran Sejarah Islam merupakan contohnya. Pokok bahasan ini dapat membatasi pandangan siswa terhadap internasionalisme Islam politik yang ditransmisikan melalui materi pertumbuhan Islam ke berbagai wilayah Arab pada masa Nabi dan penyebarannya ke daerahdaerah di luarnya setelah itu, sehingga menjadi satu kawasan Islam yang diperintah oleh satu kekuasaan politik seperti Daulah Umayah, Abbasyiah dan Turki Utsmani. Pembatasan yang sama juga ditemukan dalam perkembangan politik dunia setelah Perang Dunia I maupun Perang Dunia II dalam mata pelajaran Sejarah Nasional Indonesia. Pertumbuhan nasionalisme di dunia Eropa, Asia dan Afrika dengan latar belakangnya masing-masing memberi pemahaman yang seimbang terhadap siswa bahwa politik nasionalisme sebagaimana internasionalisme politik Islam adalah keniscayaan sejarah yang berjalan sesuai dengan kondisi dunia pada saat itu. Pandangan ini diperkuat dengan ditampilkannya kerjasama non-politik antar organisasi-organisasi Islam tingkat dunia dan kerjasama antar negaranegara Islam yang bercorak kebangsaan saat ini. Dasar pandangan tentang internasionalisme Islam politik dan nasionalisme tersebut akan membawa siswa pada pemahaman yang sama tatkala dihadapkan pada pergerakan nasional Indonesia. Perlawanan terhadap para penjajah di daerah-daerah Indonesia dan perjuangan kemerdekaan Indonesia yang didominasi oleh upaya-upaya organisasi-organisasi kebangsaan menempatkan nasionalisme Indonesia sebagai keharusan alami sebagaimana negara-negara kebangsaan lain yang lahir pada saat yang relatif sama. Dengan demikian nasionalisme sebagai ideologi politik diterima siswa 
sebagai satu kenyataan sejarah, bukan satu konsep matang yang siap didiskusikan oleh para siswa tingkat menengah. Dalam hal ini dapat dilihat bahwa pengajaran politik kebangsaan di tingkat siswa menengah keagamaan tersebut bukan sesuatu yang dididikan tetapi sesuatu yang hanya diinformasikan. Meski demikian perjuangan mempertahankan kemerdekaan Indonesia, maupun berbagai pemberontakan terhadap bentuk nasionalisme Indonesia dapat melahirkan semangat cinta tanah air dan jiwa patriotisme dalam membela paradigma kebangsaan dan Indonesia sebagai sebuah bangsa. Berlainan dengan hal itu, dalam konsep Islam terdapat jihad sebagai bentuk patriotisme yang berfungsi membela agama Islam secara universal, tanpa sekat teritorial. Konsep ini menempatkan agama Islam, bukan bangsa, sebagai prioritas pembelaan. Begitu pula dengan sistem pengaturan harta rampasan perang yang terdapat dasar hukumnya dalam fikih meniscayakan ketidakseimbangan antara patriotisme bangsa dengan patriotisme Islam (jihad). Kondisi ini membutuhkan pengajaran konsep jihad dalam sudut pandang fikih kontemporer. Keseimbangan terjadi tatkala konsep jihad ini dilihat dalam kerangka perlawanan terhadap kolonialisme sebagai bentuk ketidakadilan, perampasan tanah air, dan ancaman terhadap eksistensi keberagamaan (Islam). Dalam hal ini apabila patriotisme kebangsaan dinilai dari sudut pandang jihad, bukan sebaliknya, maka pembelaan terhadap nation-state Indonesia merupakan bagian dari jihad Islam. Begitu pula dengan Khilâfah, yang terdapat dalam materi pelajaran Fikih, sebagai bentuk pemerintahan dalam sistem politik Islam lebih bersifat internasional sebagai internasionalisme Islam politik dibandingkan dengan konsep nasionalisme dalam suatu nation-state seperti Indonesia. Bentuk Khilâfah -sebagai negara yang berdasarkan Islam- yang didukung oleh fakta sejarah umat Islam pernah mempergunakan sistem pemerintahan ini, disertai jaminan terhadap pemberlakuan syariat Islam (termasuk di dalamnya struktur dan kultur politik Islam) akan meniscayakan ketidakseimbangan yang sama dalam konteks kebangsaan Indonesia. Karenanya konsep pemahaman tentang bentuk dan struktur negara dari sudut pandang fikih kontemporer perlu dimasukan dalam mata pelajaran yang sesuai. Jika tidak, Pancasila yang dihadirkan dalam semua kurikulum sebagai dasar nasionalisme Indonesia pun akan sulit diterima, karena negara Indonesia dilihat sebagai negara yang tidak didasarkan pada Islam dan ini berarti syariat Islam tidak dilaksanakan di Indonesia. Kelahiran Pancasila dan dinamika kehidupan politik bangsa Indonesia pasca kemerdekaan yang diajarkan kepada siswa memiliki andil nilai keseimbangan terhadap keputusan Pancasila sebagai dasar negara. Konflik ideologi politik yang dipelajari siswa pada pokok bahasan tersebut dapat memberi pemahaman bahwa Pancasila merupakan kesepakatan bersama (declarated truth) ${ }^{17}$ antara unsur-unsur yang membentuk Indonesia sebagai bangsa. Berkaitan dengan struktur politik seperti lembaga eksekutif, legislatif dan yudikatif, serta pemilu baik yang dibahas dalam pelajaran fikih sebagai bagian dari sistem politik Islam maupun pelajaran PPKn, PSPB dan

${ }^{17}$ Istilah tersebut diambil dari Nurcholis Madjid, "Relevansi Pancasila di Era Globalisasi," dalam Sulastomo dan Tommi A. Legowo (ed.), Memadukan Langkah Membangun Indonesia Masa Depan (Jakarta: Gerakan Jalan Lurus, 2003), h. 65. 
Tata Negara dalam paradigma sistem politik nasional Indonesia tidak ditampilkan sebagai dua sistem yang bertolak belakang. Bahkan konsep struktur politik Islam sebagaimana disebut di atas memperlihatkan unsur-unsur kesamaan dengan struktur politik yang dijalankan di Indonesia. Ini artinya struktur politik Islam tersebut merupakan sub sistem politik nasional Indonesia dan paradigma Islam dalam konteks nasionalisme diperlihatkan kepada siswa. Pola keseimbangan ini dapat diklasifikasikan dalam tabel berikut:

Tabel 9

Klasifikasi Pola Hubungan 3

\begin{tabular}{|c|c|c|}
\hline No & Politik Islam & Nasionalisme \\
\hline 1. & Internasionalisme Islam Politik & - $\quad$ Perkembangan Nasionalisme di dunia \\
\hline & & - Nasionalisme Indonesia \\
\hline 2. & Struktur Politik Islam & - Struktur Politik Indonesia \\
\hline 3. & Bentuk negara dan sistem & - Bentuk negara dan sistem \\
\hline & pemerintahan & $\begin{array}{l}\text { pemerintahan di wilayah-wilayah Islam } \\
\text { - } \quad \text { entuk negara dan sistem } \\
\text { pemerintahan di Indonesia }\end{array}$ \\
\hline 4. & Jihad & - Patriotisme Bangsa \\
\hline
\end{tabular}

\section{Perbandingan Pendidikan Politik Era Orde Baru dan Era Reformasi}

Dikaitkan dengan runtuhnya rezim Orde Baru yang berganti menjadi Orde Reformasi, terdapat dua hal yang perlu dicermati dari pendidikan politik yang telah dilakukan oleh rezim Orde Baru ke dalam kurikulum Madrasah Aliyah pada masa itu.

Pertama. Materi-materi pelajaran yang berisi tentang kesuksesan pemerintah Orde Baru dan sistem politik yang dijalankannya yang bersifat melanggengkan kekuasaan atau status quo sebagaimana dalam mata pelajaran PPKn dan Sejarah Nasional diganti sesuai dengan kenyataan sejarah yang telah terjadi. Begitu pula dengan sistem politik dan pemilu Indonesia yang sekarang telah berubah banyak dibandingkan dengan sistem politik dan pemilu pada masa Orde Baru seperti yang disajikan dalam mata pelajaran Tata Negara. Jumlah partai politik yang kini tidak dibatasi, pemilihan anggota legislatif pusat dan daerah yang tidak lagi berdasarkan nomor urut jadi dari partai politik, pemilihan kepala pemerintahan pusat (presiden) dan daerah yang sekarang dipilih langsung. Materi-materi tentang demokrasi dan HAM yang pada masa Orde Baru memang telah ada dilanjutkan dengan penyesuaian pada internasionalisasi demokrasi dan HAM itu sendiri. Meski demikian, masyarakat Indonesia yang masih ambigu dalam menerapkan demokrasi dan HAM ala 'Barat' mesti disikapi dengan pembahasan kemungkinan demokrasi dan HAM ala Indonesia. Begitu pula dengan materimateri pendidikan politik Islam seperti struktur politik Islam dan pemilihan kepala negara melalui Majlis Syurâ yang dalam kurikulum Madrasah Aliyah masa Orde Baru dianggap selaras dengan pemilihan presiden oleh MPR, tetapi kini sudah tidak lagi sama karena Presiden 
dipilih langsung oleh rakyat dapat mengindikasikan bahwa sistem pemilu di Indonesia kini lebih tidak Islami dibandingkan masa Orde Baru.

Kedua. Upaya untuk membangun hubungan antara dua paradigm politik yang relatif tidak sama, pendidikan politik Islam dan pendidikan politik kebangsaan, dalam kurikulum Madrasah Aliyah Orde Baru di atas pada dasarnya dapat dipahami sebagai upaya sebuah negara untuk meredam paham-paham yang bersifat radikal dan aksi-aksi pemberontakan yang dikhawatirkan merusak keberadaan negara yang telah dibentuk lengkap dengan sistem politiknya. Meski rezim Orde Baru telah berganti menjadi Orde Reformasi, usaha itu pun perlu tetap dilanjutkan oleh pemerintahan pasca Orde Baru disertai perubahan-perubahan yang sesuai. Masa reformasi sekarang ini yang sangat kental dengan keterbukaan informasi, kebebasan mengeluarkan pendapat dan berkumpul, justru menjadi sebuah situasi yang jauh lebih rawan bagi generasi muda untuk menerima beragam informasi yang bertentangan dengan keberadaan Indonesia sebagai sebuah negara bangsa serta bagaimana mereka mesti bersikap. Meski lembaga pendidikan madrasah telah diakui sebagai lembaga pendidikan formal yang setara dengan SMU sebagaimana yang terdapat dalam Undang-undang Sistem Pendidikan Nasional (UU SISDIKNAS) Nomor 20 Tahun 2003, tetapi madrasah tetap dipandang sebagai representasi kelompok Islam karena materi-materi keagamaan Islamnya lebih banyak dan berfariasi, serta dikelola oleh orang-orang yang pada kenyataannya terdapat beberapa dari mereka yang masih 'radikal', dalam arti belum menerima Pancasila sebagai ideologi negara dan sistem politik Indonesia yang dianggap 'sekuler'.

Pendidikan politik yang realistik dan seimbang merupakan hal sangat penting dalam membangun karakter bangsa sebagaimana yang diamanatkan oleh UU SISDIKNAS No. 20 Tahun 2003. Karakter bangsa yang menjadi salah satu tujuan pembentukan siswa di lembaga-lembaga pendidikan tidak sekedar pada aspek moral atau akhlak saja, tapi juga bagaimana sikap warga negara dalam kehidupan berbangsa dan bernegaranya. Sejumlah ahli menyatakan bahwa pendidikan politik di lembaga pendidikan formal diperlukan agar para siswa memiliki pengetahuan, keterampilan, dan sikap tentang politik, mampu berpartisipasi dalam kegiatan-kegiatan kemasyarakatan baik yang berkaitan dengan kekuasaan maupun tidak, serta menerima dan toleran terhadap nilai-nilai politik dan sosial yang berbeda. Pendidikan politik yang seperti inilah yang diperlukan oleh remaja dalam suasana reformasi sekarang ini.

The main aim of the program has been to enchance 'political literacy' by which we mean the knowledge, skills and attitudes need to make a man or woman informed about politics, able to participate in public life and groups of all kinds both occupational and voluntary; and to recognize and tolerate diversities of political and social values. ${ }^{18}$ [...Tujuan utama program (pendidikan politik) adalah agar terjadi melek politik, yaitu pengetahuan, kete-

${ }^{18}$ B. Crick dan Alex Porter, Political Education and Political Literacy (London: Longman Group, 1978), h. 1. 
rampilan, dan sikap yang dibutuhkan oleh pria maupun wanita agar tahu tentang politik, mampu ikut serta dalam kehidupan bermasyarakat maupun kelompok yang berkaitan dengan jabatan ataupun tidak, serta menerima dan toleran terhadap beragam nilai politik dan sosial].

\section{Kesimpulan dan Saran}

Berdasarkan uraian di atas dapat disimpulkan bahwa Madrasah Aliyah di masa Orde Baru mengajarkan muatan-muatan politik nasionalisme dan politik Islam dalam kurikulumnya dengan materi-materi pendidikan politik kebangsaan (nasionalisme) lebih banyak dibandingkan dengan materi-materi pendidikan politik Islam. Pendidikan politik kebangsaan dimasukkan dalam 4 mata pelajaran, yaitu Kewarganegaraan/PMP/PPKn, Sejarah Nasional Indonesia, PSPB, dan Tata Negara. Sedangkan pendidikan politik Islam didapatkan dalam 2 mata pelajaran, yakni Fikih/Syariah dan Sejarah Islam.

Materi-materi pendidikan politik kebangsaan secara umum berisi tentang perkembangan nasionalisme dunia, nasionalisme Indonesia, Pancasila dan UUD 1945, serta pemerintah Orde Baru (status quo). Semua materi politik kebangsaan tersebut mengarahkan siswa pada pemahaman dan penerimaan bahwa Indonesia adalah sebuah nation-state dengan Pancasila sebagai dasar negara, UUD 1945 sebagai kerangka konstitusi politik negara, dan Orde Baru adalah pengemban dan pengayom ideologi nasionalisme yang berlandaskan Pancasila dan UUD 1945 tersebut.

Sedangkan pendidikan politik Islam mengajarkan materi-materi yang beruang lingkup internasionalisme Islam politik, nasionalisme Islam politik, dan Islam politik di Indonesia. Walau terdapat materi tentang internasionalisme Islam politik, tapi penyajiannya dibatasi dan ditarik kemudian dalam bingkai nasionalisme Indonesia. Penarikan ini mengarahkan siswa untuk melihat Islam dalam sudut pandang nasionalisme, tanpa disertai dengan pandangan konsep Islam terhadap nasionalisme itu sendiri.

Hubungan antara muatan politik kebangsaan dan keislaman terjadi melalui 3 pola, yaitu menampilkan nilai-nilai politik kebangsaan dari sudut pandang Islam, menampilkan materi-materi Islam politik dalam koridor kebangsaan, dan menampilkan materi-materi Islam politik yang diimbangi oleh materi-materi politik kebangsaan. Ketiga pola ini dapat dinilai bahwa hubungan antara muatan politik kebangsaan dan muatan politik Islam berusaha ditampilkan dalam format keseimbangan (congruence), yakni mendampingkan dua unsur atau lebih yang tidak sama menjadi satu kerangka yang sebangun (harmoni).

Mengingat keseimbangan yang dibutuhkan antara pendidikan politik kebangsaan dan keislaman bagi siswa Madrasah Aliyah, nasionalisme sebagai sebuah ideologi politik perlu diberikan tidak hanya dalam bentuk perjalanan sejarah sebagaimana yang terdapat dalam mata pelajaran Sejarah Nasional Indonesia, tapi juga konsep matang yang siap didiskusikan oleh mereka dalam mata pelajaran yang sesuai seperti Tata Negara dan Fikih ber- 
dasarkan sudut pandang Islam moderat. Dengan demikian terdapat keseimbangan antara konsep nasionalisme dengan kenyataan sejarah yang sudah dan sedang terjadi. Dalam konteks yang sama, mata pelajaran Fikih perlu pula menampilkan pandangan-pandangan baru Fikih tentang bentuk dan struktur negara, serta sistem politik, ditambah penerapannya di dunia Islam dalam mata pelajaran yang sesuai seperti Sejarah Islam dan Sejarah Nasional Indonesia.

Untuk menghindari kemungkinan radikalisme Islam, mata pelajaran Sejarah Islam dan Fikih lebih baik tidak lagi memberikan pokok bahasan yang berkonotasi kekerasan seperti Perang Salib dan Jihad. Begitu pula untuk materi-materi sejarah perkembangan Islam sejak masa Nabi sampai dengan Turki Utsmani, lebih baik difokuskan pada pembahasan peradabannya, tidak pada pembahasan perang.

\section{Pustaka Acuan}

Apter, David E. Pengantar Analisa Politik, terj. Setiawan Abadi, cet. 2. Jakarta: LP3ES, 1987.

Aristoteles. Al-Siyâsah, terj. Ahmad Luthfi Sayyid. Kairo: Dâr al-Qoumiyah li al-Thiba'ah wa al-Nasyr, t.t.

Bidang Studi Syariah untuk Madrasah Aliyah jilid 1a, 1b, 2a, 2b, 3a, 3b. t.t.p: Bagian Proyek Peningkatan Mutu Madrasah Aliyah Direktorat Jenderal Pembinaan Kelembagaan Agama Islam, Departemen Agama, 1985/1986.

Bungin, Burhan (ed.). Analisis Data Penelitian Kualitatif Pemahaman Filosofis dan Metodologis ke Arah Penguasaan Model Aplikasi, cet. 2. Jakarta: RajaGrafindo Persada, 2003.

Crick, B., dan Alex Porter. Political Education and Political Literacy. London: Longman Group, 1978.

Instruksi Presiden Republik Indonesia Nomor 12 Tahun 1982 tentang Pendidikan Politik bagi Generasi Muda dan Keputusan Badan Koordinasi Penyelenggaraan Pembinaan dan Pengembangan Generasi Muda Nomor: 01/BK Tahun 1982 tentang Petunjuk Pelaksanaan Pendidikan Politik Bagi Generasi Muda. Jakarta: Kantor Menteri Negara Pemuda dan Olahraga, 1985.

Kurikulum 1984 Madrasah Aliyah Garis-garis Besar Program Pengajaran (GBPP), Mata Pelajaran: Pendidikan Moral Pancasila (PMP). t.t.p: Departemen Agama, 1989.

Kurikulum 1984, Mata Pelajaran: Fikih. t.t.p: Departemen Agama, 1989.

Kurikulum 1984, Mata Pelajaran: Pendidikan Sejarah Perjuangan Bangsa (PSPB). t.t.p: Departemen Agama, 1989.

Kurikulum 1984, Mata Pelajaran: Sejarah dan Peradaban Islam. t.t.p: Departemen Agama, 1989 Kurikulum Madrasah Aliyah, Mata Pelajaran: Sejarah dan Kebudayaan Islam. t.t.p: Direktorat Jenderal Kelembagaan Agama Islam, 1995/1996.

Kurikulum 1984, Mata Pelajaran: Sejarah Nasional dan Dunia. t.t.p: Departemen Agama, 1989. 
Kurikulum 1984, Mata pelajaran: Tata Negara. t.t.p: Departemen Agama, 1989.

Kurikulum Madrasah Aliyah Agama Islam Negeri (MAAIN). Jakarta: Direktorat Jenderal Bimbingan Masyarakat Islam Direktorat Pendidikan Agama, 1973.

Kurikulum Madrasah Aliyah Garis-garis Besar Program Pengajaran (GBPP), Mata Pelajaran: Pendidikan Pancasila dan Kewarganegaraan (PPKn). t.t.p: Direktorat Jenderal Pembinaan Kelembagaan Agama Islam, 1995/1996.

Kurikulum Madrasah Aliyah, Mata Pelajaran: Fikih. t.t.p: Direktorat Jenderal Kelembagaan Agama Islam, 1995/1996.

Kurikulum Madrasah Aliyah, Mata Pelajaran: Sejarah Nasional dan Umum. t.t.p: Direktorat Jenderal Kelembagaan Agama Islam, 1995/1996.

Kurikulum Madrasah Aliyah, Mata pelajaran: Tata Negara. t.t.p: Direktorat Jenderal Kelembagaan Agama Islam, 1995/1996.

Nafsichin, Syafiie, et al., Sejarah Nasional Indonesia Untuk SMA/MAN. Jakarta: Dharma Bhakti, 1981.

Naning, Ramdlon (ed.). Pendidikan Politik dan Regenerasi. Yogyakarta: Liberty, 1982

Piaget, Jean. Strukturalisme, terj. Hermoyo. Jakarta: Yayasan Obor Indonesia, 1995

Ruslan, Utsman Abdul Mu'iz. Pendidikan Politik Ikhwanul Muslimin. Solo: Intermedia, 2000

Sejarah dan Kebudayaan Islam untuk Madrasah Aliyah, jilid IA, IB, IIA, IIB, IIIA, IIIB. Semarang: Toha Putra, 1981.

SM, Ismail SM, dan Abdul Mukti (ed.). Pendidikan Islam, Demokratisasi dan Masyarakat Madani. Yogyakarta: Pustaka Pelajar, 2000.

Sukmadinata, Nana Syaodih. Pengembangan Kurikulum Teori dan Praktek. Bandung: Remaja Rosdakarya, 2007.

Sulastomo dan Tommi A. Legowo (ed.), Memadukan Langkah Membangun Indonesia Masa Depan. Jakarta: Gerakan Jalan Lurus, 2003.

Zais, Robert S. Curriculum Principles and Foundations. New York: Harper \& Row Publisher, 1976. 